\title{
Seasonal and age-related variations of plasma concentrations of androgens and prolactin in crossbred (3/4 wild, 1/4 domestic) boars
}

\author{
Joanna Gromadzka-Ostrowska ${ }^{1}$, B. Barcikowski ${ }^{2}$ \\ and Barbara Zalewska ${ }^{3}$ \\ 'Department of Dietetics, Warsaw Agricultural University \\ Nowoursynowska I66, 02-787 Warsaw, Poland \\ ${ }^{2}$ The Kielanowski Institute of Animal Physiology and Nutrition, \\ Polish Academy of Sciences \\ 05-110 Jablonna, Poland \\ ${ }^{3}$ Warsaw Zoological Garden \\ Ratuszowa 1/3, 03-46I Warsaw, Poland
}

(Received 6 May 1999; accepted 7 October 1999)

\section{ABSTRACT}

Plasma androgen and prolactin levels were determined by radioimmunoassay in 9 male crossbred ( $3 / 4$ wild, $1 / 4$ domestic) boars between 4 and 26 months of age. The boars were kept in outdoor enclosures.

Androgen concentrations showed a clear seasonal pattern with the highest level in November; $6.48 \pm 1.31 \mathrm{ng} / \mathrm{ml}$ and $13.44 \pm 1.39 \mathrm{ng} / \mathrm{ml}$ during the first and second year of life, respectively. Data for the two years studied well demonstrated age-related androgen level variations with an elevation between 5 and 7 month of life $(1.74 \pm 0.18 \mathrm{ng} / \mathrm{ml})$ and maximum in 13 month-old boars $(6.48 \pm 1.31 \mathrm{ng} / \mathrm{ml})$.

The prolactin level was low at 4 months of age $(0.57 \pm 0.22 \mathrm{ng} / \mathrm{ml})$, increased until 9.10 months $(24.45 \pm 2.04 \mathrm{ng} / \mathrm{ml})$ and decreased thereafter. Higher values were observed during the summer months $(24.33 \pm 2.07 \mathrm{ng} / \mathrm{ml})$ as compared with the rest of the year.

It seems that there is a seasonal and age interaction in androgen concentrations with a predominance of season-related changes.

KEY WORDS: androgens, growth, wild-boar hybrids, prolactin, season

\footnotetext{
1 Corresponding author
} 


\section{INTRODUCTION}

European wild boars are true, short-day seasonal breeders (Mauget, 1985). The breeding season starts in late autumn, all wild boar females are anoestrus between July and September (Mauget, 1987; Delcroix et al., 1990). Testis size and testosterone levels of wild boars are significantly lower in the summer months compared to winter (Schopper et al., 1984; Mauget, 1987).

Some reports in the literature suggest that the domestic pig also has a seasonal breeding pattern with a reduction in fertility in the late summer and early autumn (Claus et al., 1983) and photoperiod is now accepted as the major environmental factor which affects seasonal variations (Love et al., 1993). Information is available on seasonal variations of androgens (Claus et al., 1983; Schopper et al., 1984) and prolactin (Ravault et al., 1982; Mauget, 1985) as well as age-related androgen variations (Colenbrander et al., 1978; FlorCruz and Lapwood, 1978; Tan and Reaside, 1978) in domestic and wild boars. Knowledge of the seasonal hormonal changes in both wild and domestic, European and US pig breeds is, however, rather scanty and no data are available for wild $\mathrm{x}$ domestic crossbred pigs.

The purpose of this investigation, therefore, was to determine whether plasma androgen and prolactin concentrations vary during growth and/or between seasons in wild $\mathrm{x}$ domestic pigs.

\section{MATERIAL AND METHODS}

\section{Animals and blood sampling}

Crossbred (Polish wild pig x Zlotnicka domestic pig) sows were bred with Polish wild boars. Products from this crossing were born in the Warsaw Zoological Garden and were used for the experiment. These animals looked like original hogs with dense dark bristles, a short and broad head with a long massive muzzle, strong short body with long legs and straight hairy tail. Up to 6 months of life the animals had a striped coat like young wild boars.

Nine of these crossbred males were kept in outdoor enclosures, in natural climatic conditions and fed a standard diet consisting of potatoes, wheat bran, ground barley, powdered skimmed milk, common salt, vitamins and minerals. Animal carcasses were given occasionally. Males attained full sexual maturity at 13 months of age (full sexual and mating behaviour was observed). To minimize blood sampling stress, all animals were adapted to handling from 2 months of age.

Blood collection started at 4 months of age and lasted for 15 months. Boars were caught at the particular months of the year by hand without the aid of drugs and bled by ear venipuncture between 09:00 and 10:00 in the morning. All blood 
samples were collected at the same time of the day to minimize possible diurnal fluctuations in plasma hormone levels. Plasma was obtained by centrifugation and stored at $-23^{\circ} \mathrm{C}$ until assayed.

\section{Hormone assays}

Plasma concentrations of androgens were determined without extraction by radioimmunoassay according to Stupnicki (1985) using a rabbit antibody (aT/R7) (Institute of Animal Physiology and Nutrition, Jabłonna, Poland) specific for testosterone and DHT. No cross-reactions with other androgens were observed. The sensitivity of the assay was $12.5 \mathrm{pg} / \mathrm{ml}$ of plasma. The intra- and interassay coefficients of variation were 6.0 and $14.0 \%$, respectively.

Plasma prolactin concentrations were also determined by a highly specific double-antibody radioimmunoassay method using purified porcine prolactin (KK-2 purified by K. Kochman, Institute of Animal Physiology and Nutrition, Jabłonna, Poland) as the antigen. Details were described previously by Gromadzka-Ostrowska et al. (1985). The antibody showed no cross-reaction with purified porcine GH, $\mathrm{LH}$ and ACTH. The sensitivity of the assay was $0.20 \mathrm{ng} / \mathrm{ml}$ of plasma. The intraand interassay coefficients of variation were 3.0 and $10.0 \%$, respectively.

\section{Statistical analyses}

Mean values and their standard errors (SEM) for each investigated month were calculated. Statistically significant differences for both hormones between particular months were analyzed using the Student t-test and a paired-t test for each month from two years. The influence of month was tested by ANOVA analyses of variance, one for each year, using the computer statistics program (Stagraphics Plus version 3.0). The correlation between hormone concentrations and daylight length was also assayed using the same computer program.

\section{RESULTS}

\section{Plasma androgen concentration changes}

Age-related androgen concentration changes during 22 months were observed. This concentration rose from $0.84 \pm 0.16 \mathrm{ng} / \mathrm{ml}$ in four-month-old boars to $1.65 \pm 0.19$ and $1.74 \pm 0.18 \mathrm{ng} / \mathrm{ml}$ in five- and seven-month-olds, concurrently with the change of coat and rapid growth. Concentrations decreased below the first value and increased again to $2.24 \pm 0.39 \mathrm{ng} / \mathrm{ml}$ in twelve-month-old males, reaching a peak $(6.48 \pm 1.31 \mathrm{ng} / \mathrm{ml})$ in thirteen-month-old boars that were sexually pubertal. During 
the next twelve months androgen concentrations fluctuated between $2.98 \pm 0.34$ and $1.81 \pm 0.23 \mathrm{ng} / \mathrm{ml}$. In twenty-four and twenty-five-month-old fully mature males, plasma concentrations of androgens were very high ranging from $9.65 \pm 1.67$ to $13.44 \pm 1.39 \mathrm{ng} / \mathrm{ml}$ (Figure 1).

As shown by ANOVA analyses of variance, the influence of the month as well as the influence of age on androgen concentrations were significant $(F=31.2$, $\mathrm{P}<0.00001$ and $\mathrm{F}=24.06, \mathrm{P}<0.0001$ ). Changes connected with age and month of the year were also confirmed by a paired-t test between particular months from the two years of the investigation. For all months the differences between years was significant (Figure 1). During the two years maximal androgen concentrations were observed in November, which coincides with the early stage of the breeding season in wild boar populations. There was also a simple negative correlation between androgen concentration and daylight duration $(r=-0.44, \mathrm{P}<0.05)$.

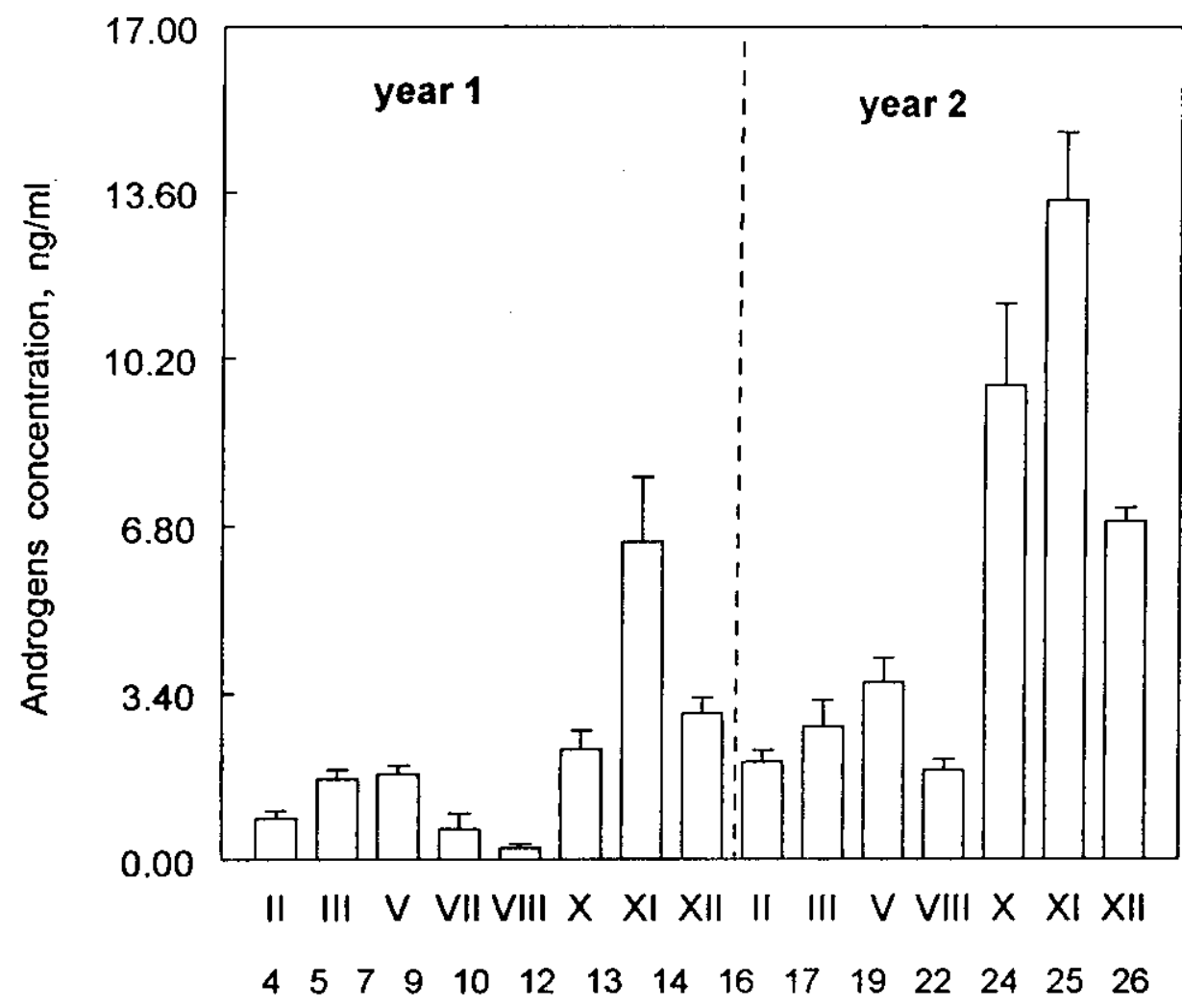

Figure 1. Growth and seasonal effects on plasma androgens concentration (mean \pm SEM) in crossbred boars. Arabic numerals indicated months of age, Roman numerals indicated months of the year 


\section{Prolactin concentration changes}

As shown in Figure 2, prolactin concentrations changed according to the animal's age and season. The peripheral plasma prolactin level rose gradually from $0.57 \pm 0.22 \mathrm{ng} / \mathrm{ml}$ at four months of age to $24.2 \pm 3.6 \mathrm{ng} / \mathrm{ml}$ at 9 months of age.

During the first year, the highest prolactin concentrations were observed in July and August. Season-related prolactin changes during this year were also confirmed as statistically significant by ANOVA variance analysis $(\mathrm{F}$ ratio $=63.7$, $\mathrm{P}<0.0000)$. A significant correlation between prolactin concentration and daylight duration $(\mathrm{r}=0.79 ; \mathrm{P}<0.01)$ was also found.

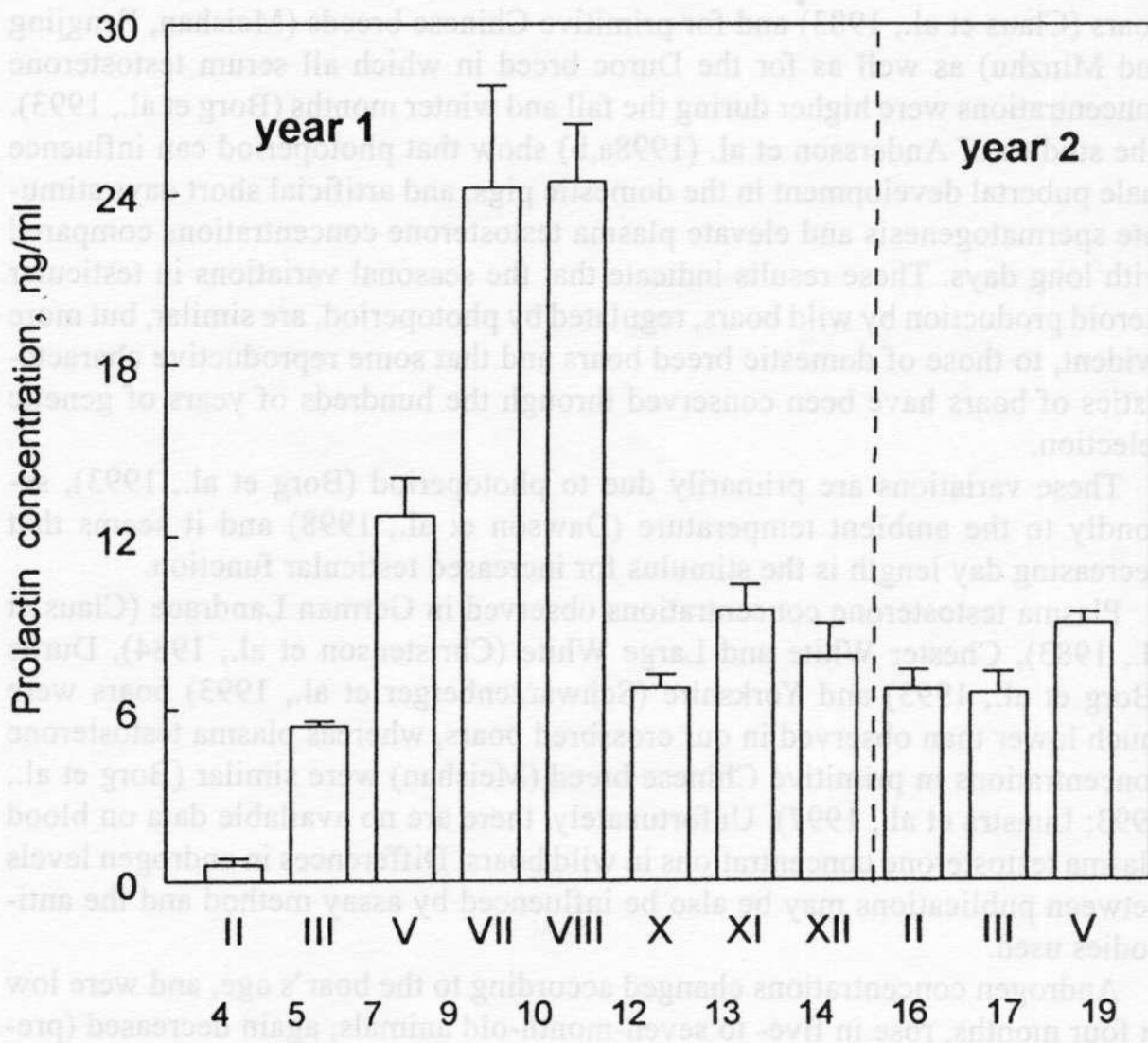

Figure 2. Growth and seasonal effects on plasma prolactin concentration (mean $\pm \mathrm{SEM}$ ) in crossbred boars. Explanations as for Figure 1 


\section{DISCUSSION}

In crossbred ( $3 / 4$ wild and $1 / 4$ domestic) boars, our data showed that plasma androgens follow a clear seasonal pattern with the highest levels in autumn. Similar results were obtained by Schopper et al. (1984) in wild boars showing a clear seasonal pattern of seminal plasma androgens with the highest concentrations in late autumn and early winter and lowest levels from January to July. In contrast with the wild pig, steroid production in the domesticated boar is not considered to be affected by season, however, sexually inactive domestic boars (German Landrace) kept under natural light conditions showed a pronounced increase in $5 \alpha$-androst-16-en-3-one (boar's pheromone) in late autumn and early winter (Claus, 1979) coinciding with the breeding season of wild pigs. Seasonal variations in testicular function with maximum concentrations from October to December have been also described for sexually active German Landrace boars (Claus et al., 1983) and for primitive Chinese breeds (Meishan, Fengjing and Minzhu) as well as for the Duroc breed in which all serum testosterone concentrations were higher during the fall and winter months (Borg et al., 1993). The studies of Andersson et al. (1998a,b) show that photoperiod can influence male pubertal development in the domestic pigs, and artificial short days stimulate spermatogenesis and clevate plasma testosterone concentrations compared with long days. These results indicate that the seasonal variations in testicular steroid production by wild boars, regulated by photoperiod, are similar, but more evident, to those of domestic breed boars and that some reproductive characteristics of boars have been conserved through the hundreds of years of genetic selection.

These variations are primarily due to photoperiod (Borg et al., 1993), secondly to the ambient temperature (Dawson et al., 1998) and it seems that decreasing day length is the stimulus for increased testicular function.

Plasma testosterone concentrations observed in German Landrace (Claus et al., 1983), Chester White and Large White (Christenson et al., 1984), Duroc (Borg et al., 1993) and Yorkshire (Schwarzenberger et al., 1993) boars were much lower than observed in our crossbred boars, whereas plasma testosterone concentrations in primitive Chinese breed (Meishan) were similar (Borg et al., 1993; Lunstra et al., 1997). Unfortunately, there are no available data on blood plasma testosterone concentrations in wild boars. Differences in androgen levels between publications may be also be influenced by assay method and the antibodies used.

Androgen concentrations changed according to the boar's age, and were low at four months, rose in five- to seven-month-old animals, again decreased (prepubertal till puberty), reaching the highest values at thirteen months of life (sexual maturity). Age-related androgen changes were observed in Yorkshire 
(Schwarzenberger et al., 1993) and other common domestic boars (Colenbrander et al., 1978; FlorCruz and Lapwood, 1978; Tan and Reaside, 1987) with low values between two to six months of life and marked increases thereafter. The different age-related changes in androgens in our crossbred boars were probably due to their slow pubertal development and later onset of puberty. This confirms our hypothesis that in wild $\mathrm{x}$ domestic crossbred boars, age-related hormonal events are probably more similar to those in wild than in domestic boars.

In crossbred boars, seasonal variations in plasma prolactin were observed with the highest levels in July and August and lowest levels during winter months. The peak concentration occurred during midsummer and nadir in winter, suggesting that photoperiod is a prominent factor in the regulation of the annual cycle of prolactin secretion in these animals. Similar observations have been made in wild boars and sows by Ravault et al. (1982), who reported the highest levels in June (sows) and July (boars) and lowest in both sexes during winter. The same trend has been observed in ovariectomized gilts (Ravault et al., 1982). On the other hand, Andersson et al. (1998a) observed that plasma prolactin concentrations were higher in boars kept under a short photoperiod than those from a long light regime. According to observations of other authors (Ravault et al., 1982; Bassett et al., 1995) no seasonal prolactin variations existed in intact gilts and boars.

The role of prolactin in the control of reproductive function in this species is not completely clear, but photoperiod is now accepted as a major environmental factor affecting reproductive characteristics (Love et al., 1993). It is possible that high prolactin concentrations during summer contribute to reduced LH and consequent steroid secretion, although this has not been tested (Dawson et al., 1998). The results of Mauget et al. (1990) also indicated that wild pigs are sensitive to photoperiod, which may regulate reproduction through diurnal variations in melatonin secretion by the pineal gland and subsequent modifications in gonadotrophin secretion. As in other mammalian species (Pévet et al., 1991; Elloranta et al., 1995) melatonin is probably the neuroendocrine „,mediator" in pigs (Love et al., 1993), but in this species diurnal patterns of melatonin are confusing and a nocturnal rise is not always observed (Paterson et al., 1992). In other species, transduction of photoperiodic information is achieved by release of melatonin during the dark period (Pévet et al., 1991). In the pig, the pattern of melatonin secretion and the subsequent hypothalamo-pituitary-gonadal responses appear to be more complex: a relatively high light intensity is required for pigs to generate a diurnal melatonin rhythm (Love et al., 1993). The pituitary response to different photoperiods in pigs is also confusing. Pigs may respond to bright light with greater secretion of prolactin (Griffith and Minton, 1992).

It seems that in crossbred boars changes in androgen and prolactin levels are directly related to the annual changes of photoperiod and age-related variations in androgen concentrations are secondary to seasonal these seasonal patterns. 


\section{ACKNOWLEDGMENTS}

The authors wish to thank Mrs. K. Jakubów for technical assistance, Dr. K. Kochman for the gift of the anti-PRL antibody.

\section{REFERENCES}

Andersson H., Rydhmer L., Lundstrom K., Wallgren M., Anderson K., Forsberg M., 1998a. Influence of artificial light regimens on sexual maturation and boar taint in entire male pigs. Anim. Reprod. Sci. 51, 31-43

Andersson H., Wallgren M., Rydhmer L., Lundstrom K., Andersson K., Forsberg M., 1998b. Photoperiodic effects on pubertal maturation of spermatogenesis, pituitary resposiveness to exogenous GnRH and expression of boar taint in crossbred boars. Anim. Reprod. Sci. 54, 121-137

Bassett J.M., Bray C.J., Sharpe C.E., 1995. Summer infertility in outdoor sows: lessons from studies on ,seasonally barren” sows. Pig J. 36, 65-85

Borg K.E., Lunstra D.D., Christenson R.K., 1993. Semen characteristics, testicular size, and reproductive hormone concentrations in mature Duroc, Meishan Fengjing and Minzhu boars. Biol. Reprod. 49, 515-521

Colenbrander B., de Jong F.H., Wensing C.J.G., 1978. Changes in serum testosterone concentrations in the male pig during development. J. Reprod. Fertil. 53, 377-380

Christenson R.K., Ford J.J., Redmer D.A., 1984. Estradiol and testosterone metabolic clearance and production rates during pubertal development in boars. Biol. Reprod. 31, $905-912$

Claus R., 1979. Pheromone bei Säugetieren unter besonderer Berücksichtigung des Ebergeruchstoffes und seiner Beziehung zu anderen Hodensteroiden. Fortschr. Tierphysiol. Tierernähr. No 10

Claus R., Schopper D., Wagner H.G., 1983. Seasonal effect on steroids in blood plasma and seminal plasma of boars. J. Steroid Biochem. 19, 725-729

Dawson A., Pitt R., Peters A.R., 1998. Seasonality and reproduction. In: J. Wiseman, M.A. Varley, J.P. Chadwick (Editors). Progress in Pig Science. Nottingham University Press, pp. 327-342

Delcroix I., Mauget R., Signoret J.P., 1990. Existence of synchronization of reproduction at the level of the social group of the European wild boar (Sus scrofa). J. Reprod. Fertil. 89, 613-617

Eloranta E., Timisjarvi J., Nieminen M., Leppaluoto J., Vakkuri O., 1995. Seasonal onset and disappearance in female reindeer. Amer. Zool. 35, 203-214

FlorCruz S.V., Lapwood K.R., 1978. A longitudinal study of pubertal development in boars. Int. J. Androl. 1, 317-330

Griffith M.K., Minton J.E., 1992. Effect of light intensity on circadian profiles of melatonin, prolactin, ACTH and cortisol in pigs. J. Anim. Sci. 70, 492-498

Gromadzka-Ostrowska J., 1980. Hormonal patterns during oestrus cycle in primitive pigs (in Polish). Ph.D. Thesis, Warsaw University, Poland

Gromadzka-Ostrowska J., Madej A., Barcikowski B., 1985. Peripheral plasma prolactin concentrations during oestrus cycle in different types of primitive pigs. J. Reprod. Fertil. 73, $159-164$

Love R.J., Evans G., Klupiec C., 1993. Seasonal effects on fertility in gilts and sows. J. Reprod. Fertil., Suppl. 48, 191-206

Lunstra D.D., Ford J.J., Klindt J., Wise T.H., 1997. Physiology of the Meishan boar. J. Reprod. Fertil., Suppl. 52, 181-193 
Mauget R., 1985. Seasonality of reproduction in the wild boar. In: D.J.A. Cole, G.R. Foxcroft (Editors). Control of Pig Reproduction. Butterworth Scientific, London, pp. 509-526

Mauget R., 1987. Reproductive biology of the European wild boar. In: E.Seren. M. Mattioli (Editors). Definition of the Summer Infertility Problem in the Pig. Commission of the European Communities, Brussels, pp. 107-119

Mauget R., Ravault J.P., Chesnau D., Locatelli A., Saboreau M., Sempere A.J., Lacroix A., 1990. Peripheral plasma melatonin concentrations in the European wild boar: Circadian and seasonal variations. J. Reprod. Fertil., Suppl. 40, 371 (Abstr.)

Paterson A.M., Martin G.B., Foldes A., Maxwell C.A., Pearce G.P., 1992. Concentrations of plasma melatonin and LH in domestic gilts reared under artificial long or short days. J. Reprod. Fertil. 94, 85-95

Pévet P., Vivien-Roels B., Masson-Pévet M., 1991. Annual changes in the daily pattern of melatonin synthesis and release. In: J.C. Fraschini. S.R. Reiter (Editors). Role of Melatonin and Pineal Peptides in Neuroimmunomodulation. Plenum Press, New York, pp. 147-157

Ravault J.P., Martinat-Botte F., Mauget R., Martinat N., Locatelli A., Bariteau F., 1982. Influcnce of the duration of daylight on prolactin secretion in the pig: hourly rhythm in ovariectomized females, monthly variation in domestic (male and female) and wild strains during the year. Biol. Reprod. 27, 1084-1089

Schopper D., Gaus J., Claus R., Bader H., 1984. Seasonal changes of steroid concentrations in seminal plasma of European wild boar. Acta Endocrinol. 107, 425-427

Schwarzenberger F., Toole G.S., Christie H.L., Reaside J.I., 1993. Plasma levels of several androgens and estrogens from birth to puberty in male domestic pigs. Acta Endocrinol. 128, 173-177

Stupnicki R., 1985 Testosteron In: F. Kokot, R. Stupnicki (Editors). Radiommunoassay and Radiocompetition Methods Applied in Clinics (in Polish). PZWL, Warszawa, pp. 273-281

Tan H.S., Reaside J.I., 1987. Developmental patterns of plasma DHEAS and testosterone in male pigs. Anim. Reprod. Sci. 3, 73-81

\section{STRESZCZENIE}

Sezonowe i związane z wiekiem zmiany stężenia androgenów i prolaktyny u knurów mieszańców (3/4 dzika i $1 / 4$ świni domowej)

W osoczu krwi obwodowej 9 knurów ( $3 / 4$ dzik, 1/4 świnia domowa) w wieku od 4 do 26 miesięcy oznaczano stężenie androgenów i prolaktyny metodą RIA.

Stçżenie androgenów było najwyższe w listopadzie i wyższe w 2 roku życia knurów w porównaniu z pierwszym rokiem życia $(6,48 \pm 1,31 \mathrm{i} 13,44 \pm 1,39 \mathrm{ng} / \mathrm{ml})$. W ciagu pierwszego roku życia knurów stwierdzono pierwszy wzrost stężenia androgenów między 5 a 7 miesiąccm $(1,74 \pm 0,18 \mathrm{ng} / \mathrm{ml})$ i drugi, maksymalny wzrost w 13 miesiącu $(6,48 \pm 1,31 \mathrm{ng} / \mathrm{ml})$.

Stężenie prolaktyny było wyższe latem w czasie długich dni $(24,33 \pm 2,07 \mathrm{ng} / \mathrm{ml})$ w porównaniu $z$ krótkimi dniami zimowymi. 